\title{
PENINGAKATAN EKONOMI MASYARAKAT MELALUI PEMBERDAYAN PEREMPUAN PESISIR DI DESA OLELE KABUPATEN BONE BOLANGO
}

\author{
Juliana $^{1}$, Yuniarti Koniyo ${ }^{2}$ \\ ${ }^{1}$ Universitas Negeri Gorontalo. Email: juliana@ung.ac.id \\ 2Universitas Negeri Gorontalo. Email: yuniarti.koniyo@ung.ac.id
}

\begin{abstract}
Olele Village is one of the villages located in Bone Bolango Regency and is included in the Coastal Region. Most Olele villagers have livelihoods as fishermen, so most Olele village women are fishermen's wives. The purpose of community service activities carried out in Olele village is to increase community income through empowering coastal women. The method used consists of two forms, namely counseling and training. Coastal women who were participants in service activities were 30 fishermen wives. The material provided in counseling is about the types of diversification of processed products and fisheries processing techniques. Training is provided through hands-on practice and assistance during service activities. The products produced are fish fingers, dragon foot fish, jelly, pudding, and crackers which will be sold to increase community income especially for fishermen's wives. The results of community service activities carried out in the village of Olele are increased knowledge and skills diversification of processed fisheries products for fishermen wives who have received service activities. Community service activities also provide increased income for the community through the sale of various processed fishery products.
\end{abstract}

Keywords: Fish Finger, Foot Dragon Fish, Jelly Candy, Pudding, and Fish Crackers.

\begin{abstract}
ABSTRAK
Desa olele merupakan salah satu desa yang terletak di Kabupaten Bone Bolango dan termasuk wilayah pesisir. Penduduk desa Olele sebagian besar memiliki mata pencaharian sebagai nelayan, sehingga sebagian besar perempuan desa Olele merupakan istri nelayan. Tujuan kegiatan pengabdian yang dilakukan di desa Olele yaitu untuk meningkatkan pendapatan masyarakat melalui pemberdayaan perempuan pesisir. Metode yang digunakan terdiri dari dua bentuk yaitu penyuluhan dan pelatihan. Perempuan pesisir yang dijadikan peserta pada kegiatan pengabdian adalah istri-istri nelayan sebanyak 30 orang. Materi yang diberikan pada penyuluhan yaitu tentang jenis diversifikasi produk olahan dan teknik pengolahan hasil perikanan. Pelatihan diberikan dengan cara praktek langsung dan pendampingan selama kegiatan pengabdian berlangsung. Produk yang dihasilkan adalah fish finger, foot dragon fish, permen jell, puding, dan kerupuk yang akan dijual untuk meningkatkan pendapatan masyarakat khususnya bagi istri-istri nelayan. Hasil kegiatan pengabdian yang dilakukan di desa Olele yaitu peningkatan pengetahuan dan keterampilan tentang diversifikasi produk olahan perikanan bagi istri-istri nelayan yang telah mengikuti kegiatan pengabdian. Kegiatan pengabdian juga memberikan dampak bagi peningkatan pendapatan masyarakat melalui penjualan diversifikasi produk olahan perikanan.
\end{abstract}

Kata Kunci: Kaki Naga, Kerupuk, Nugget, Permen dan Puding.

\section{PENDAHULUAN}

Luas perairan laut desa Olele mencapai $7.400 \mathrm{~km}^{2}$ di Teluk Tomini dan $43.100 \mathrm{~km}^{2}$ di laut Sulawesi yang merupakan wilayah koridor pantai utara pulau Sulawesi. Panjang garis pantai 198,00 Km2 yang menjadi garis pantai terpanjang di provinsi Gorontalo yang 
berhadapan dengar Samudra Pasifik (Dinas Perikanan dan Kelautan Kabupaten Gorontalo Utara, 2015.). Wilayah ini, memiliki potensi sumberdaya perikanan dan kelautan yang bernilai ekonomis penting, di antaranya ikan pelagis, ikan demersal, rumput laut dan berbagai binatang laut lainnya, jasa-jasa lingkungan dan sumberdaya tidak pulih. Disamping itu masyarakatnya memiliki keterkaitan yang kuat dengan pesisir-laut sehingga menjadi potensi kekuatan sosial-budaya yang sangat signifikan.

Desa Olele merupakan salah satu desa yang terletak di Kabupaten Bone Bolango dan termasuk dalam kategori desa pesisir. Hal ini menyebabkan desa Olele memiliki potensi Perikanan dan Kelautan yang besar, salah satu sektor unggulan yang dijadikan prioritas dalam struktur ekonominya adalah sector perikanan dan kelautan. Pekerjaan utama masyarakat desa Olele sebagai nelayan, sedangkan ibu-ibu rumah tangga sebagian besar juga membantu suami dalam bidang perikanan. Ketergantungan pada penangkapan membuat masyarakat harus mampu mengatasi ekonomi pada keadaan cuaca yang tidak mendukung penangkapan. Pada waktu tertentu, hasil tangkapan melimpah sehingga dibutuhkan pengetahuan untuk mengolah hasil tangkapan sehingga dapat bertahan lebih lama dan menghasilkan produk dengan nilai jual yang lebih baik.

Kelompok Perempuan Pesisir yang ada di Desa Olele adalah kelompok yang sudah terbentuk sejak tahun 2012, merupakan pelaku ekonomi informal sector perikanan dan kelautan secara langsung maupun tidak langsung (Dinas Perikanan dan Kelautan Kabupaten Gorontalo Utara ,2015). Karena diantara perempuan pesisir tersebut ada yang bermata pencaharian sebagai pedangang kios, pedagang warung makan, pengolah ikan, pedagang pengumpul ikan, pembuat jaring, dan terlibat memperbaiki sarana penangkapan yang rusak atau memperbaiki sarana penangkapan pada musim penceklik. Artinya peran perempuan pesisir dalam menunjang ekonomi keluarga sangat besar.

Berdasarkan kondisi dilapangan kelompok perempuan pesisir pengolah ikan masih melakukan proses pengolahan secara turun temurun atau tradisional. Hal ini dikarenakan kurangnya pengetahuan dan keterampilan dalam mengolah dan mendiversifikasi pengolahan hasil perikanan, sehingga belum optimal memberikan kontribusi dalam peningkatan pendapatan ekonomi keluarga. Oleh karena itu peran ini perlu dikembangkan sehingga memberikan out put dan out come yang memiliki efisiensi ekonomi tinggi. Melalui kegiatan Pemberdayaan Ekonomi Perempuan Pesisir (PE2P) melalui Program Kemitraan Masyarakat. Salah satunya adalah Pemberdayaan Ekonomi Perempuan Pesisir (PE2P) Melalui Diversifikasi Pengolahan Produk Perikanan untuk meningkatkan kesejahteraan dan enkonomi keluarga.

\section{METODE PELAKSANAAN}

Metode yang digunakan dalam melakukan pemberdayaan kelompok sasaran adalah pelatihan dengan teknik pembelajaran partisipatif dan pendampingan, praktek langsung di lapangan. Peserta pada kegiatan pengabdian adalah istri-istri nelayan desa Olele sebanyak 30 orang. Pembelajaran dan praktek akan dilakukan oleh mahasiswa bersama kelompok sasaran yang didampingi dosen pendamping lapangan. mahasiswa sebagai tenaga teknis terlebih dahulu dibekali dengan pengetahuan praktis yang sesuai dengan kebutuhan target kegiatan pengabdian yang akan dilakukan. Hal ini dilakukan 
agar mahasiswa sebagai pendamping telah memiliki pengetahuan tentang program yang akan dilaksanakan, sehingga dapat dengan mudah mentransfer pengetahuan tersebut ke kelompok sasaran (istri-istri nelayan).

Langkah-langkah operasional yang diperlukan untuk mengatasi Permasalahan adalah proses pendampingan penyelesaian masalah tentang pemilihan bahan baku produk olahan, menyusun formulasi bahan-bahan olahan hasil perikanan, teknologi pengolahan, melakukan diversifikasi pengolahan hasil perikanan berupa fish finger, foot dragon fish, permen jelly, puding dan kerupuk ikan, mengetahui proses pengemasan dan manajemen pemasaran.

\section{HASIL DAN PEMBAHASAN}

Kegiatan pengabdian yang telah dilakukan dengan menggunakan metode penyuluhan dan pelatihan dengan sasaran mengaplikasikan ilmu pengetahuan dan teknologi (IPTEK) tentang diversifikasi produk olahan hasil perikanan. Penerapan IPTEK diawali dengan cara memberikan penyuluhan tentang sarana dan prasarana yang dibutuhkan, cara pemilihan bahan baku, pengolahan produk sampai dengan teknik pemasaran. Penyuluhan dilakukan dengan tujuan meningkatkan pengetahuan bagi perempuan pesisir khususnya istri-istri nelayan yang menjadi peserta pada kegiatan pengabdian di desa Olele. Tahap selanjutnya yaitu memberikan pelatihan secara langsung bagi seluruh peserta kegiatan pengabdian di desa Olele untuk meningkatkan keterampilan, agar semua peserta dapat melakukan diversifikasi produk olahan perikanan.

Diversifikasi produk olahan hasil perikanan yang dilakukan di desa Olele terdiri dari lima produk yaitu nugget (fish finger), kaki naga (foot dragon fish), permen jelly, puding dan kerupuk ikan. Tahapan kegiatan pelatihan yang dilakukan di desa Olele, diuraikan sebagai berikut:

\section{Pemilihan Bahan}

Tahapan pertama yang dilakukan pada kegiatan pengabdian bagi perempuan pesisir di Desa Olele yaitu cara memilih bahan-bahan yang akan digunakan pada pelaksanaan diversifikasi produk olahan perikanan. Bahan-bahan yang akan digunakan terdiri dari bahan utama dan bahan tambahan. Bahan utama yaitu daging ikan yang dihaluskan dan rumput laut segar atau tepung rumput laut. Daging ikan yang digunakan harus benar-benar segar dan hanya bagian daging yang akan digunakan karena akan dijadikan daging ikan lumat. Sedangkan untuk pembuatan permen jelly dan puding digunakan tepung rumput laut, agar lebih praktis dan mudah untuk pengolahan selanjutnya. Bahan tambahan yang digunakan akan disesuaikan dengan jenis produk olahan yang akan dibuat berdasarkan komposisi kebutuhan bahan. Pemilihan bahan pada kegiatan diversifikasi produk olahan perikanan sangat menentukan kualitas produk yang akan dihasilkan, sehingga sangat penting untuk diperhatikan. 


\section{Penentuan Jenis Produk Olahan Perikanan}

Setelah melakukan tahapan pemilihan bahan baku dilanjutkan dengan menentukan jenis produk yang akan dibuat pada kegiatan pengabdian. Pada kegiatan pengabdian ini, produk yang akan dibuat terdiri dari lima jenis produk olahan(Dinas Perikanan dan Kelautan Provinsi Gorontalo, 2015). Produk olahan yang dibuat menggunakan dua bahan baku utama yaitu daging ikan lumat dan tepung rumput laut. Produk olahan yang berbahan baku daging ikan lumat berupa nugget, kaki naga, dan kerupuk ikan. Dua jenis produk lainnya berbahan dasar tepung rumput laut yaitu permen jelly dan puding.

\section{Pembuatan Produk Olahan}

Tahapan yang paling penting pada kegiatan pengabdian di desa Olele adalah tahap pembuatan produk olahan hasil perikanan. Pembuatan produk olahan perikanan dilakukan melalui beberapa tahapan berdasarkan jenis produk olahan yang akan dibuat. a. Nugget (Fish Finger)

Fish finger merupakan makanan yang terbuat dari ikan. fingers rnerupakan suatu produk yang terbuat dari potongan daging ikan atau daging ikan giling atau bentuk surimi, kemudian dilapisi dengan batter dan breadcrumbs lalu digoreng setengah matang dan kemudian dibekukan.

Peralatan untuk pengolahan Fish Finger: Meat bone separator, mixer/grinder, alat leaching/pembilasan, pan pembeku, freezer, dan penggorengan (deep frier), sedangkan bahan-bahan yang digunakan dalam pembuatan nuget dapat dilihat pada Tabel 1.

Tabel 1. Bahan bahan yang Digunakan untuk Fish Finger

\begin{tabular}{lc}
\hline \multicolumn{1}{c}{ Bahan } & Jumlah (gr) \\
\hline Daging Ikan Lumat & 745 \\
Tepung Terigu & 120 \\
Tepung Maizena & 100 \\
Bawang Putih & 10 \\
Lada & 2 \\
Gula & 10 \\
Garam & 15 \\
Baking Powder & 5 \\
Air Es & Secukupnya \\
telur & 3 butir \\
Tepung Roti & Secukupnya \\
Minyak & Secukupnya \\
\hline
\end{tabular}

\section{Cara Pengolahan}

1) Bahan baku ikan segar dicuci, dipisahkan dagingnya dan digiling dengan menggunakan blender/gilingan daging

2) Daging yang telah lumat dicampur dengan garam dan diaduk/diremas-remas hingga homogen.

3) Masukkan tepung terigu ke dalam adonan dan terus diaduk, tambahkan air es ke dalam adonan 
4) Masukkan bumbu-bumbu yang telah dihaluskan, gula dan minyak sayur

5) Adonan yang terbentuk berupa pasta kemudian dicetak dalam Loyang dengan ketebalan 1,5 cm dan dikukus

6) Adonan yang telah dikukus dipotong pada suhu $10^{\circ} \mathrm{C}$ dengan ukuran $1 \mathrm{~cm} \mathrm{x} \mathrm{1,5} \mathrm{cm} \mathrm{x}$ $6 \mathrm{~cm}$.

7) Potongan tersebut dicelupkan kedalam telur, lalu dilumuri tepung roti dan dilakukan flash fry pada suhu $185^{\circ} \mathrm{C} \mathrm{s} / \mathrm{d} 190^{\circ} \mathrm{C}$ selama 1 menit.

8) Setelah dingin disusun dalam wadah pengemasan, ditutup secara vakum atau non vakum dan dibekukan.

b. Kaki Naga (Foot Dragon Fish)

Kaki naga (Foot Dragon Fish) merupakan makanan yang terbuat dari daging ikan yang telah dilumatkan. Kaki naga ikan adalah salah satu jenis olahan berbentuk bulat agak lonjong dan ditusuk dengan tusukan sate, telah diperdagangkan secara komersial di pasar lokal dengan variasi bahan baku dari ikan atau udang (Dinas Perikanan dan Kelautan Provinsi Gorontalo, 2015). Bahan dan alat yang digunakan untuk pembuatan kaki naga sama dengan pembuatan nugget, yang berbeda adal bentuk dan proses pengolahannya.

Peralatan untuk pengolahan Fish Finger: Meat bone separator, mixer/grinder, alat leaching/pembilasan, pan pembeku, freezer, dan penggorengan (deep frier), sedangkan bahan-bahan yang digunakan dalam pembuatan kaki naga dapat dilihat pada Tabel 2.

Tabel 2. Bahan bahan yang Digunakan untuk Fish Finger

\begin{tabular}{lc}
\hline \multicolumn{1}{c}{ Bahan } & Jumlah (gr) \\
\hline Daging Ikan Lumat & 745 \\
Tepung Terigu & 120 \\
Tepung Maizena & 100 \\
Bawang Putih & 10 \\
Lada & 2 \\
Gula & 10 \\
Garam & 15 \\
Baking Powder & 5 \\
Air Es & Secukupnya \\
telur & 3 butir \\
Tepung Roti & Secukupnya \\
Minyak & Secukupnya \\
\hline
\end{tabular}

\section{Cara Pengolahan}

1) Bahan baku ikan segar dicuci, dipisahkan dagingnya dan digiling dengan menggunakan blender/gilingan daging

2) Daging yang telah lumat dicampur dengan garam dan diaduk/diremas-remas hingga homogen.

3) Masukkan tepung terigu ke dalam adonan dan terus diaduk, tambahkan air es ke dalam adonan

4) Masukkan bumbu-bumbu yang telah dihaluskan, gula dan minyak sayur 
5) Adonan yang terbentuk berupa pasta kemudian dicetak dalam Loyang dengan ketebalan $1,5 \mathrm{~cm}$

6) Adonan kemudian langsung dibentuk bulat lonjong dan diberi tusuk sate atau tusuk es krim sebagai pegangan.

7) Adonan yang telah dibentuk tersebut dicelupkan kedalam telur, lalu dilumuri tepung roti dan dilakukan flash fry pada suhu $185^{\circ} \mathrm{C}$ s/d $190^{\circ} \mathrm{C}$ selama 1 menit.

8) Setelah dingin disusun dalam wadah pengemasan atau dapat langsung digoreng agar dapat dikonsumsi

c. Kerupuk Ikan

Kerupuk ikan merupakann kerupuk produk hasil periikanan yang terbuat dari campuran daging ikan dan bumbu-bumbu/bahan pembantu lainnya yang melewati proses pengadonan, percetakan, perebusan/pengukusan, pengirisan dan pengiringan. Tujuan dari pembuatan kerupuk ikan adalah diversifikasi olahan hasil perikanan agar produk dapat bertahan lama (awet) sehingga dapat dikonsumsi dengan aman (Dinas Perikanan dan Kelautan Kabupaten Gorontalo Utara, 2015).

Peralatan yag digunakan yaitu kompor, wajan, baskom plastik, blender atau mesin penggiling, piring, talenan, serok, pisau kecil, solil serta penumbuk bumbu, sedangkan bahan-bahan pembuat kerupuk ikan dapat dilihat pada Tabel 3.

Tabel 3. Bahan bahan yang Digunakan untuk Kerupuk Ikan

\begin{tabular}{lc}
\hline \multicolumn{1}{c}{ Bahan } & Jumlah \\
\hline Daging Ikan Lumat & $200 \mathrm{gr}$ \\
Tepung Terigu & 120 \\
Tepung Kanji & 400 \\
Gula & $30 \mathrm{gr}$ \\
Garam & $15 \mathrm{gr}$ \\
Baking Powder & $1 \mathrm{sdt}$ \\
Penyedap & $1.5 \mathrm{sdt}$ \\
telur & $2 \mathrm{butir}$ \\
Minyak & Secukupnya \\
\hline
\end{tabular}

\section{Cara Pengolahan}

1) Kocok telur bersama gula, garam, penyedap jamur hingga berbuih

2) Tambahkan ikan, aduk rata. Tambahkan larutan amoniak, uleni hingga rata.

3) Tambahkan tepung, kaldu, baking powder, aduk rata. Pulung adonan, bentuk bulat panjang seperti telur ikan atau sesuai selera.

4) Rendam dalam minyak dingin. Nyalakan kompor, pertama gunakan api besar. Setelah krupuk amplang terapung, kecilkan api. Goreng hingga matang. Angkat, tiriskan

\section{d. Pudding}

Puding banyak variannya, tergantung keinginan kita untuk melakukan variasi rasa berdasarkan kesukaan setiap orang yang akan disesuaikan dengan bahan yang akan kita campurkan sebagai bahan pembuatan puding tersebut. Puding merupakan nama 
untuk berbagai macam jenis hidangan yang digunakan sebagai hidangan penutup dengan bahan dasar rumput laut yang direbus atau dikukus dengan campuran air dan bahan tambahan lainnya (Direktorat Jenderal Penguatan Daya Saing Produk Kelautan dan Perikanan, 2015).

Peralatan yang digunakan untuk pembuatan puding antara lain kompor, panci, glas ukur, timbangan, pengaduk dan loyang, sedangkan bahan-bahan yang digunakan untuk pembuatan puding dapat dilihat pada Tabel 4.

Tabel 4. Bahan bahan yang Digunakan untuk Puding

\begin{tabular}{lc}
\hline \multicolumn{1}{c}{ Bahan } & Jumlah \\
\hline Tepung rumput laut & $50 \mathrm{gr}$ \\
Air & $500 \mathrm{ml}$ \\
Gula Pasir & $200 \mathrm{gr}$ \\
Susu & $200 \mathrm{ml}$ \\
Essence & $1 \mathrm{gr}$ \\
Pewarna Makanan & Secukupnya \\
\hline
\end{tabular}

Cara pengolahan

1) Rumput laut kering dipotong-potong lalu dicuci sampai bersih dan kemudian direndam selama 1 malam

2) Rumput laut yang telah direndam kemudian direbus dalam air dan susu dengan perbandingan minimal $250 \mathrm{ml}$ susu untuk $1 \mathrm{~kg}$ rumput laut

3) Ditambahkan sedikit gula, essence, garam, dan pewama

4) Setelah mendidih, segera diangkat dan dituangkan kedalam loyang cetakan

5) Didinginkan di dalam lemari es.

6) Selanjutnya siap untuk dikonsumsi

e. Permen Jelly

Permen Jelly merupakan salah satu jenis makanan jajanan yang sangat digemari baik anak-anak maupun orang dewasa. Rasa dan bentuk dari permen jelly beraneka ragam, biasanya ada yang berbentuk boneka yang unik sehingga sangat menarik bagi anak-anak. Salah satu ciri khas permen jelly adalah teksturnya yang kenyal sehingga memberikan sensasi tersendiri ketika dikunyah atau dikonsumsi (Dinas Perikanan dan Kelautan Kabupaten Gorontalo Utara, 2015).

Peralatan yang digunakan pada proses pembuatan permen jelly cukup sederhana, antara lain panci, gelas atau ceret ukur, pengaduk, dan kompor. Bahan-bahan yang digunakan untuk pembuatan permen jelly dapat dilihat pada Tabel 5.

Tabel 5. Bahan bahan yang Digunakan untuk Puding

\begin{tabular}{lc}
\hline \multicolumn{1}{c}{ Bahan } & Jumlah \\
\hline Tepung rumput laut tanpa rasa & $1 \mathrm{bks}$ \\
Tepung rumput Laut dengan perasa & $1 \mathrm{bks}$ \\
Air & 200 \\
Gula Pasir & $200 \mathrm{gr}$ \\
Pewarna Makanan & 3 tetes \\
\hline
\end{tabular}




\section{Pemasaran}

Pemasaran oleh para ahli memiliki definisi yang beragam, tetapi memiliki makna yang sama yaitu memindahkan barang dari produsen atau penghasil ke pengguna atau pembeli atau konsumen. Pemasaran adalah proses manajerial yang dilakukan oleh individu ataupun kelompok dalam memperoleh kebutuhan dan keinginan mereka, dengan cara membuat dan mempertukarkan produk dan nilai dengan pihak lain (Adawiyah, 2011). Sedangkan ahli lain menyatakan bahwa pemasaran bertujuan untuk memenuhi kebutuhan dan keinginan individu maupun organisasi. Pemasaran adalah kegiatan memasarkan barang atau jasa umumnya kepada masyarakat. Aktivitas pemasaran bermula dari pengamatan kebutuhan konsumen (Direktorat Jenderal Penguatan Daya Saing Produk Kelautan dan Perikanan, 2015).

Pada dasarnya kegiatan pemasaran diawali dari kebutuhan atau keinginan konsumen terhadap suatu produk termasuk produk perikanan. Berdasarkan kebutuhan atau keinginan konsumen, barulah dibuat produk. Sedangkan kegiatan penjualan, diawali dengan membuat produk, dan dengan gencar berusaha bagaimana produk tersebut laku dijual. Dalam kegiatan pemasaran dituntut kreatifitas lebih dominant daripada promosi. Sedangkan pada kegiatan penjualan, promosi lebih dominant bahkan sampai menipu konsumen, yang penting produk terjual habis. Kalau kita menerapkan kegiatan pemasaran maka kepuasan konsumen akan menjadi harapan atau tujuannya. Sebaliknya penjualan, tidak memperhatikan kepuasan konsumen yang penting barang terjual habis (Nurjanah, 2011)

Jika kita menerapkan kegiatan pemasaran, maka kontinuitas kegiatan akan terjamin. Tanpa pemasar (marketer) berusaha mencari pembeli untuk membeli barangnya, pembeli akan datang atau mencari marketer atau produsen. Yang saya tekankan disini bahwa jika pemasaran berawal dari kebutuhan dan keinginan konsumen, maka kebutuhan atau keinginan tersebut menyangkut kebutuhan akan keamanan pangan terhadap kesehatan manusia dan lingkungan. Dengan demikian menurut pendapat saya kebutuhan masyarakat tersebut tidak hanya dari aspek ekonomi yaitu bagaimana memilih kebutuhan yang sesuai dengan kemampuan ekonomi konsumen, namun lebih dari itu adalah adanya keseimbangan antara ekonomi, sosial dan ekologi.

\section{SIMPULAN}

Hasil kegiatan pengabdian yang dilakukan di desa Olele memberikan manfaat yang dapat membantu masyarakat desa Olele khususnya perempuan pesisir yang telah mengikuti kegiatan pengabdian untuk meningkatkan tingkat ekonomi keluarganya. Transfer teknologi diversifikasi produk olahan perikanan menunjukkan bahwa $100 \%$ dari seluruh peserta pelatihan yang terlibat dalam kegiatan ini telah mampu membuat berbagai produk hasil diversifikasi produk olahan perikanan seperti nuget, kaki naga, kerupuk ikan, permen jelly dan puding. Hasil kegiatan ini telah diproduksi secara berkelompok dan dipasarkan di sekolah dan di warung-warung sekitra desa Olele. 


\section{UCAPAN TERIMA KASIH}

Ucapan terimakasih kepada Kepala Desa Olele, ibu-ibu desa Olele yang terlibat langsung sebagai peserta dalam kegiatan pengabdian dan masyarakat serta seluruh pihak yang telah membantu terlaksananya Program Kemitraan Masyarakat di Desa Olele. Ucapan terima kasih juga disampaikan secara khusus pada Kemenristek Dikti yang telah memberikan bantuan dana dalam bentuk Hibah Program Kemitraan Masyarakat Tahun Anggaran 2019.

\section{DAFTAR RUJUKAN}

Adawiyah. (2011) Pengolahan dan Pengawetan Ikan. Penerbit Bumi Aksara. Jakarta. 160 page.

Dinas Perikanan dan Kelautan Provinsi Gorontalo. (2015). Provinsi Gorontalo Dalam Angka 2015. Bappeda dan BPS Provinsi Gorontalo.

Dinas Perikanan dan Kelautan Kabupaten Gorontalo Utara (2015). Profil Perikanan dan Kelautan Gorontalo Utara.

Direktorat Jenderal Penguatan Daya Saing Produk Kelautan dan Perikanan (2014). Pengembangan Produk Hasil Perikanan. Kementerian Kelautan dan Perikanan.

Direktorat Jenderal Penguatan Daya Saing Produk Kelautan dan Perikanan. (2015) Pengembangan Produk Hasil Perikanan. Kementerian Kelautan dan Perikanan.

Nurjanah, Abdullah, A., Tarman, K. (2011). Pengetahuan dan Karakteristik Bahan Baku Hasil Perairan. Bogor (ID): IPB Press. 
120 J-Abdipamas, Vol. 3, No. 2 Oktober, 2019 